\title{
THE SHADOWS OF FUTURE GENERATIONS
}

\author{
MATTHEW W. WOLFE $\dagger$
}

\begin{abstract}
This Note addresses the twin problems of political short-termism and intergenerational equity. Although scholars have discussed these concerns extensively, few scholars have developed proposals to modify democratic institutions - particularly legislatures-to better consider posterity's interests. This Note critiques one such set of proposals by several environmental ethicists for including posterityoriented legislators in present-generation legislatures. It then proposes a system that ties the long-term outcomes of legislators' policy preferences to their pension plans by creating a new commodities market that values the decisions legislators make and their effect on posterity.
\end{abstract}

'Tis not the concern of a day, a year, or an age; posterity are virtually involved in the contest, and will be more or less affected, even to the end of time, by the proceedings now. ${ }^{1}$

\section{INTRODUCTION}

New Orleans, Louisiana is situated largely below sea level between the Mississippi River and Lake Pontchartrain. ${ }^{2}$ Its geography

Copyright (C) 2008 by Matthew W. Wolfe.

$\dagger$ Duke University School of Law, J.D. expected 2008; Duke University Sanford Institute of Public Policy, M.P.P. expected 2008; University of Rochester, B.A. 2003. I thank Professor Paul Carrington for reviewing an earlier draft of this Note. I am also grateful for the extensive feedback from Michael Rosenberg, Erin Blondel, and Jeffrey Chemerinsky and the careful work of the editors of the Duke Law Journal. I dedicate this Note to my former students, my present children, and my future one(s).

1. Thomas Paine, Common Sense 18 (Stanley Appelbaum \& Ronald Herder eds., Dover Publ'ns, Inc. 1997) (1776).

2. Greater New Orleans Cmty. Data Ctr., New Orleans Elevation by NEIGHBORHOOD WITH MAJOR ROADS (2005), available at http://www.gnocdc.org/maps/PDFs/ neworleans_elevation.pdf. 
naturally creates the potential for flooding, ${ }^{3}$ a risk that the region's susceptibility to frequent hurricanes exacerbates. ${ }^{4}$ Thus, New Orleans's natural environment invites disaster, as destructive hurricanes throughout the city's history have demonstrated. ${ }^{5}$ A levee system was constructed in the 1940s to provide better protection to the city, but three subsequent hurricane strikes indicated that New Orleans remained vulnerable to flooding. ${ }^{6}$ After each disaster, politicians promised to prevent a similar catastrophe, and each time they failed to follow through and adequately fix the levees. ${ }^{7}$ An assessment of the levee system conducted after Hurricane Katrina concluded: "New Orleans has now been flooded by hurricanes six times over the past century; in 1915, 1940, 1947, 1965, 1969, and 2005. It should not be allowed to happen again."

According to a White House report evaluating its aftermath and the implications for disaster preparedness relief, "Hurricane Katrina was the most destructive natural disaster in U.S. history." "The estimated property damage was $\$ 96$ billion with 300,000 homes made uninhabitable; 118 million cubic yards of debris were left behind; an estimated 1,330 people lost their lives to the storm and ensuing flood (with many at the time of the report still missing); the survivors, many displaced, have spent years piecing their lives back together. New Orleans is not the same-and may never be..$^{10}$

3. White House, The Federal Response to Hurricane Katrina: Lessons LEARNED 24 (2006), available at http://www.whitehouse.gov/reports/katrina-lessons-learned.pdf.

4. See 1 R.B. Seed et Al., Investigation of the Performance of the NeW OrLEANS FloOd PROTECTION SYSTEMS IN HURRICANE KATRINA ON AUGUST 29, 2005, ch. 4, at 9 (2006), available at http://www.ce.berkeley.edu/ new_orleans/report/VOL_1.pdf ("Since 1759, 172 hurricanes have struck southern Louisiana. Of these, 38 have caused flooding in New Orleans, usually via Lake Pontchartrain. Some of the more notable events have included: 1812, 1831, 1860, 1893, 1915, 1940, 1947, 1965, 1969, and 2005." (citation omitted)).

5. Id. ch. 4 , at $10-11$.

6. Id. ch. 4 , at $11-12$.

7. See, e.g., id. ch. 15, at 2 ("The northeast flank of the St. Bernard/Ninth Ward basin's protecting 'ring' of levees and floodwalls was incomplete at the time of Katrina's arrival. The critical 11 mile long levee section fronting 'Lake' Borgne... was being constructed in stages, and funding appropriation for the final stage had long been requested ... but this did not arrive before Katrina struck; as a result large portions of this critical levee frontage were several feet below final design grade.").

8. Id. at xxv; see also WHITE House, supra note 3, at 9 ("By any measure, Hurricane Katrina was a national catastrophe. Similar to the images of grief and destruction on September 11, 2001, the images of suffering and despair from Hurricane Katrina are forever seared into the hearts and memories of all Americans. Those painful images must be the catalyst for change.").

9. White House, supra note 3, at 5.

10. Id. at 7-9. 
As the Times-Picayune, New Orleans's local newspaper, surmised, "[n]o one can say they didn't see it coming." "The paper published a five-part series predicting this type of disaster in 2002. ${ }^{12}$ Even the Federal Emergency Management Agency (FEMA) recognized this threat as one of the top three most worrisome scenarios in early 2001. ${ }^{13}$ Adequate measures were not taken to prevent the tragedy. Thus, when Hurricane Katrina hit, the levee system was still defective. ${ }^{14}$

In the aftermath of Hurricane Katrina, many policymakers and scholars attempted to explain the underlying political and social conditions that contributed to the catastrophe. ${ }^{15}$ Even though they recognized that the levee system could fail in the event of another hurricane, ${ }^{16}$ past generations ignored calls after each hurricane for

11. Bill Walsh, Bruce Alpert \& John McQuaid, Feds' Disaster Planning Shifts Away from Preparedness, TIMES-PICAYUNE (New Orleans), Aug. 31, 2005, at A10, available at http://www. nola.com/katrina/pages/. On top of the masthead for this issue, a tag read "Katrina: The Storm We've Always Feared." Id.

12. John McQuaid \& Mark Schleifstein, Exposure's Cost, TIMES-PICAYUnE (New Orleans), June 25, 2002, at A1; John McQuaid \& Mark Schleifstein, In Harm's Way, TIMESPICAYUNE (New Orleans), June 23, 2002, at J2; John McQuaid \& Mark Schleifstein, Shifting Tides, Times-PICAYune (New Orleans), June 26, 2002, at A14; John McQuaid \& Mark Schleifstein, Tempting Fate, TIMES-PICAYUNE (New Orleans), June 26, 2002, at A1; John McQuaid \& Mark Schleifstein, The Big One, TIMES-PICAYUne (New Orleans), June 24, 2002, at A1; see also Jim Wilson, New Orleans is Sinking, PopUlar MECHANICS, Sept. 2001, at 42, 42, available at $\mathrm{http}: / / \mathrm{www}$.popularmechanics.com/science/research/1282151.html ("During a strong hurricane, the city could be inundated with water blocking all streets in and out for days, leaving people stranded without electricity and access to clean drinking water. Many also could die ....”).

13. See Eric Berger, New Orleans Faces Doomsday Cenario [sic], Houston Chron., Dec. 1, 2001, http://www.chron.com/disp/story.mpl/nation/1153609.html ("[E]arlier this year [FEMA] ranked the potential damage to New Orleans as among the three likeliest, most castastrophic [sic] disasters facing this country."); see also Jia-Rui Chong \& Hector Becerra, California Earthquake Could Be the Next Katrina, L.A. TIMES, Sept. 8, 2005, at A1 ("[I]n August 2001 ... [FEMA] ... discussed the three most likely catastrophes to strike the United States. First on the list was a terrorist attack in New York. Second was a super-strength hurricane hitting New Orleans. Third was a major earthquake on the San Andreas fault.”).

14. See generally SEED ET AL., supra note 4, ch. 2 (noting that the levees were "virgin" levees constructed on swampy foundation soil and were not completed by the time that Hurricane Katrina struck).

15. See, e.g., White House, supra note 3 (policymakers); Symposium, Thirty-Sixth Annual Administrative Law Issue, 56 DUKE L.J. 1 (2006) (scholars).

16. See Hurricane Katrina in New Orleans: A Flooded City, a Chaotic Response: Hearing Before the S. Comm. on Homeland Security \& Governmental Affairs, 109th Cong. 7 (2005) (statement of Marty Bahamonde, Regional Director, Federal Emergency Management Agency) (labeling Hurricane Katrina as "the worst-case scenario that everyone had always talked about regarding the City of New Orleans"); Mark Fischetti, The Drowning of New Orleans, SCI. AM., Oct. 2001, at 76, 78 (warning that only an enormous engineering overhaul could prevent a 


\begin{abstract}
better protection and did not fortify the levee system. ${ }^{17}$ Politicians responded with short-term relief rather than measures that would prevent the next disaster. ${ }^{18}$ The disparity between long-term social needs and short-term political will contributed to Hurricane Katrina's eventual devastation. ${ }^{19}$
\end{abstract}

catastrophic flood from engulfing New Orleans); John McQuaid \& Mark Schleifstein, Evolving Danger, TIMES-PICAYUNE (New Orleans), June 23, 2002, at J12 ("That margin of error is critical because a storm that pushes the lake any higher can force water over the top of the levees and inundate the city. The water could rise 20 feet or higher. People would drown, possibly in great numbers.").

17. Recognizing this problem, then-Homeland Security Advisor Frances Townsend wrote of Hurricane Katrina:

We must expect more catastrophes like Hurricane Katrina-and possibly even worse. In fact, we will have compounded the tragedy if we fail to learn the lessons-good and bad-it has taught us and strengthen our system of preparedness and response. We cannot undo the mistakes of the past, but there is much we can do to learn from them and to be better prepared for the future. This is our duty.

White House, supra note 3, at 65; see also Russell S. Sobel \& Peter T. Leeson, Government's Response to Hurricane Katrina: A Public Choice Analysis, 127 PUB. CHOICE 55, 68 (2006) (noting the widespread recognition of the inability of the New Orleans levee system to withstand a hurricane and attributing the failure to invest in a better system to "political shortsightedness bias").

18. See SEED ET AL., supra note 4, ch. 2, at 6 ("Construction of the first phase of the levees along this frontage began in the late 1960's. The last major work in this area prior to Katrina had been the construction of the third phase, in 1994-95. Since that time, the USACE had been waiting for Congressional appropriation of the funds necessary to construct the final stage .... Now it is too late."); Robert J. Meyer, Why We Under-Prepare for Hazards, in ON RISK AND DisASTER: LESSONS FROM HURRICANE KATRINA 153, 156-57 (Ronald J. Daniels, Donald F. Kettl \& Howard Kunreuther eds., 2006) ("A case example of such a truncated learning process might be found in the repeated decisions by state and federal governments to under-fund flood control projects in greater New Orleans prior to Hurricane Katrina.... Reducing funding (combined with cost overruns) forced planned dates of completion to be postponed.... In addition, recommendations made in 1982 to upgrade the original plan for the height of the levees around New Orleans was never funded."); see also Howard Kunreuther, Disaster Mitigation and Insurance: Learning from Katrina, ANNALS AM. ACAD. POL. \& SOC. SCI., Mar. 2006, at 208, 209 ("Extensive evidence indicates that residents in hazard-prone areas do not undertake loss prevention measures voluntarily.").

19. See SEED ET AL., supra note 4, ch. 1, at 3-4 (concluding that "global 'organizational' and institutional problems associated with the governmental and local organizations responsible for the design, construction, operation, maintenance and funding of the overall flood protection system" contributed to the catastrophe of Hurricane Katrina). Commentators have noted the dangerous disconnect between short-term political will and long-term needs:

This failure to invest current resources for future benefit can be explained by the widely-recognized "shortsightedness" bias in government decision making. Political decision makers are biased toward current over future benefits. Perhaps nothing illustrates this more than the lack of investments made in strengthening the levees themselves in the years-even decades-prior to Katrina. The levee system in New Orleans was widely-recognized as incapable of sustaining trauma from a major hurricane. 
Political rhetoric boasting that a decision taken in the present will have a positive impact on the lives of generations to come is appealing. But as the example of New Orleans demonstrates, political rhetoric frequently surpasses political action. Levees may protect present-generation voters, but future generations also can enjoy the benefit of a vibrant, well-protected city that has not suffered a catastrophe like Hurricane Katrina. That future generations will benefit only if current generations pay is an example of an intergenerational externality, ${ }^{20}$ which leads to an underinvestment in disaster protection. After all, future generations do not vote for the present-day politicians who make the decisions, even though the decisions require a calculated tradeoff among different generations.

Politicians, ${ }^{21}$ ethicists, ${ }^{22}$ scholars, ${ }^{23}$ and everyday citizens ${ }^{24}$ often champion the needs of future generations on issues from hurricane protection to climate change and from pension reform to public education. Yet policymaking decisions often do not adequately

Sobel \& Leeson, supra note 17 , at 68 . The issue of a levee system inadequate to withstand a strong hurricane is not a local one. See, e.g., Samantha Young, FEMA: Calif. Levees Worse Than Thought, WASHINGTONPOST.COM, Jan. 4, 2007, http://www.washingtonpost.com/wp-dyn/ content/article/2007/01/03/AR2007010302037.html ("Federal and state governments are taking another look at widespread flood risks in the wake of Hurricane Katrina.").

20. One economics text defines "externality" as "an effect of one economic actor's activities on another actor's well-being that is not taken into account by the normal operations of the price system." WALTER NiCHOLSON, INTERMEDiATE MicroeCONOMICS AND ITS APPLICATION 530 (9th ed. 2004). In this case, the actors whose well-being is not being considered in the price system are future persons.

21. See President George W. Bush, President Bush Discusses the Economy and the War on Terror (Oct. 16, 2003), available at http://www.whitehouse.gov/news/releases/2003/10/200310163.html ("I came to this office to confront problems directly and forcefully, not to pass them on to future Presidents or future generations."); President George W. Bush, State of the Union Address (Feb. 2, 2005), available at http://www.whitehouse.gov/news/releases/2005/02/2005020211.html) ("To build the prosperity of future generations, we must update institutions that were created to meet the needs of an earlier time.").

22. See infra Part I.A.

23. See Anthony D'Amato, Do We Owe a Duty to Future Generations to Preserve the Global Environment?, 84 AM. J. INT'L L. 190, 190 (1990) (“A common assumption underlying nearly every book or essay on the global environment is that the present generation owes a duty to generations yet unborn to preserve the diversity and quality of our planet's life-sustaining environmental resources."); David A. Weisbach \& Cass R. Sunstein, Introduction to Symposium on Intergenerational Equity and Discounting, 74 U. CHI. L. REV. 1, 1 (2007) ("Most analysts ... take the position future generations should count, and most likely count equally to those currently alive.").

24. See Harwood Group, Yearning For Balance (1995), http://www.iisd.ca/consume/ harwood.html (reporting survey results that indicate "Americans are alarmed about the future.... [and] particularly concerned about the implications of our skewed priorities for children and future generations-they see worse trouble ahead if we fail to change course"). 
represent these needs. Despite general desires to help the future, short-term political interests tend to prevail in specific policy decisions. In this respect, concerns for posterity resemble basic constitutional commitments, such as the right to a trial by a jury or the freedom of speech. Most Americans support these commitments in general ${ }^{25}$ but might reject them in particular circumstances. ${ }^{26}$ To prevent a society from succumbing to the sirens' call to do what is expedient rather than what is right, a constitution ties the country and its leaders to a legal mast. ${ }^{27}$ For the interests of future generations in contemporary political decisionmaking, however, no such mast exists.

This Note's ultimate goal is to provoke legislatures to create institutional arrangements that tie legislators to the proverbial mast, translating their asserted commitment to posterity into action. Legislators require an incentive to legislate for future generations' needs despite the temptation of political expediency. The question remains how to design this arrangement to best represent the interests of future generations without completely sacrificing the present generation's political autonomy or other shared values. ${ }^{28}$

25. See Pub. Agenda for the Nat'l Constitution Ctr., Knowing It by Heart: AMERICANS CONSIDER THE CONSTITUTION AND ITS MEANING 9-10 (2002) (“As a whole, the American public recognizes the Constitution as a document that sets an expansive goal of freedom .... Virtually all (91\%) believe that the Constitution's fundamental purpose is 'to protect and serve the interests of all people, regardless of their wealth or power."').

26. For example, the concept of due process is almost universally supported in the abstract, but the extent to which it should be extended to an "enemy combatant" becomes far more contentious in the wake of a terrorist attack. See PEW RESEARCH CTR. FOR THE PEOPLE \& THE PRESS, AMERICA'S PLACE IN THE WORLD 2005, at 7 (2005), available at http://people-press.org/ reports/pdf/263.pdf ("The public is much more tolerant of the use of torture against suspected terrorists- $46 \%$ say it can be often or sometimes justified, while $49 \%$ believe it is rarely or never justified.").

27. See, e.g., Jon Elster, Ulysses and the Sirens: Studies in Rationality AND IRRATIONALITY 93-96 (1984) ("[C]onstitutional democracy is founded upon a set of stable institutions that cannot be undone at will once established."). For the original story of Odysseus and his plot to avoid the songs of the Sirens and thus certain death, see HOMER, THE ODYSSEY: THE STORY OF ODYSSEUS 138-47 (W.H.D. Rouse trans., Penguin Group 1937) (n.d.).

28. These values might include, for example, accountability, Alícia Adserà et al., Are You Being Served? Political Accountability and Quality of Government, 19 J.L. ECON. \& ORG. 445, 445-49 (2003), fairness, JoHn RAWLS, Political Liberalism 11-15 (1993), representation, REPRESENTATION 3-54 (J. Roland Pennock \& John W. Chapman eds., 1968), and sovereignty of the people, AlEXIS DE TOCQUeVILle, DEMOCRACY IN AMERICA 55-59 (Alfred A. Knopf, Inc. 1994) (1835). This type of constitutional revision would inevitably involve a tradeoff, but it need not require a complete delegation of political power by the citizens to an actor who exists without any temporally based interest, such as an official not accountable to the people. 
Accepting that legislatures have some obligation to future generations, how can they fulfill that obligation? ${ }^{29}$

In the American system of government, future generations have limited representation. ${ }^{30}$ In the judicial branch, litigants have experimented with representing posterity in judicial processes, although the results have been disappointing. ${ }^{31}$ In the executive branch, the interests of future generations exercise some influence in agency rulemaking. ${ }^{32}$ The agency setting occasionally provides a forum for the representation of future costs and benefits, ${ }^{33}$ but the

29. In keeping with Judge Richard Posner's call for a more fervent interdisciplinary dialogue in legal scholarship, this evaluation should not come solely from environmental ethicists or political theorists but also from legal scholars who have a capacity to analyze how such a proposal would fit into the traditional constitutional framework. See Richard A. Posner, Law, Knowledge, and the Academy: Legal Scholarship Today, 115 HARV. L. REV. 1314, 1324 (2002) ("[I]nterdisciplinary legal scholarship is still far from converging with the standard academic model, and the progress toward that convergence is slow."); see also DE TOCQUEVILLE, supra note 28, at 272-80 (describing lawyers as civic leaders); Jonathan L. Entin, The Law Professor as Advocate, 38 CASE W. RES. L. REV. 512, 514 (1987) ("Because the law occupies a uniquely powerful niche in the nation's social and political structure, law professors have enjoyed unusual access to the fora in which civic debate occurs."). Legal scholars might also be able to "peel away the veil of academia and plant scholarship firmly in a real-world setting." Clay Calvert \& Robert D. Richards, Alan Isaacman and the First Amendment: A Candid Interview with Larry Flynt's Attorney, 19 CARDOZO ARTS \& ENT. L.J. 313, 353 (2001).

30. For a discussion of how the executive and judicial branches represent, or at least attempt to represent, posterity, see Matthew W. Wolfe, Posterity's Role in Judicial and Executive Settings: Its Promise and Shortfalls (working paper, on file with the Duke Law Journal).

31. See, e.g., Lujan v. Defenders of Wildlife, 504 U.S. 555, 560 (1992) (reciting the standing requirement that the plaintiff's harm be "actual or imminent" rather than "conjectural' or 'hypothetical'” (quoting Whitmore v. Arkansas, 495 U.S. 149, 155 (1990))); see also Raymond A. Just, Comment, Intergenerational Standing Under the Endangered Species Act: Giving Back the Right to Biodiversity After Lujan v. Defenders of Wildlife, 71 TUL. L. REV. 597, 622 (1996) (“[T]he United States Supreme Court, through application of the same constitutional standing requirements which frustrated the plaintiffs in Lujan, likely would limit the effectiveness of any legislatively created right of future generations to environmental preservation.").

32. See Exec. Order No. 12,866, § 1, 3 C.F.R. 638, 639 (1993), reprinted in 5 U.S.C. $\S 601$ (2000) (requiring agencies to consider the impact of rules on future generations).

33. The Office of Management and Budget, for example, identified this analytical technique:

For transparency's sake, [the analysts] should state in their report what assumptions were used, such as the time horizon for the analysis and the discount rates applied to future benefits and costs.... The ending point [of the calculation of benefits and costs] should be far enough in the future to encompass all the significant benefits and costs likely to result from the rule.... Future citizens who are affected by such choices cannot take part in making them, and today's society must act with some consideration of their interest. 
short time horizons of legislators (who define the role of agencies and exercise oversight) or political appointees (who run these agencies) limit the effectiveness of agencies in protecting posterity. ${ }^{34}$

The legislature remains the best hope for protecting future generations. But because legislators are directly and regularly accountable to voters, they may be limited in sincerely considering future generations in decisionmaking. ${ }^{35}$ Legislatures, however, make policy decisions that have the most direct effect on future generations. They answer such crucial questions as whether it is worthwhile to spend more money on levees in New Orleans; how much should Social Security benefits for present-day senior citizens be (and thus, how much burden should the legislature heap on future taxpayers); what are the objectives of the country's public education system; what should be done about global warming? Finally, because the legislature is the branch best suited to represent the people, ${ }^{36}$ posterity representation seems natural. Yet the political representation of future generations in the legislative branch has not been seriously considered, much less attempted, beyond three related proposals by environmental ethicists. ${ }^{37}$

This Note converts the existing empty rhetoric about future generations into a concrete solution. First, it critiques the environmental ethicists' proposals to elect future-oriented legislators. It then proposes a system that creates a market for successful longterm policy outcomes and ties the legislators' pension system to the success of this market. If a major obstacle to realizing posterity

Office of Mgmt. \& Budget, Executive OfFice of the President, OMB Circular A-4, REGULATORY ANALYSIS 3, 31, 35 (2003), available at http://www.whitehouse.gov/OMB/ circulars/a004/a-4.pdf.

34. See Tyler Cowen, Caring About the Distant Future: Why It Matters and What It Means, 74 U. CHI. L. REV. 5, 6 (2007) ("When people are voting or choosing for all future generations as a whole, they often behave quite selfishly. Political time horizons tend to be low, often extending no further than the next election or the next media cycle.").

35. See infra Part I.B.

36. THE FEDERALisT No. 52, at 327 (James Madison) (Clinton Rossiter ed., 1961) ("As it is essential to liberty that the government in general should have a common interest with the people, so it is particularly essential that the [legislative] branch ... should have an immediate dependence on, and an intimate sympathy with, the people.").

37. See infra Part II. 
representation is that there is no way to represent posterity in the legislature, then this Note fills that vacuum.

This Note proceeds in three parts. Part I examines how incentives to focus on short-term concerns ${ }^{39}$ cause present-generation decisionmakers to fail to adequately consider future generations and why this intergenerational inequity should concern society. Part II summarizes three environmental ethicists' proposals to designate some number of legislators as representatives of future generations

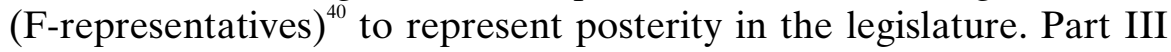
critiques these proposals and then suggests an alternate way to encourage lawmakers to legislate for posterity's interests by tying congressional pensions to the long-term performance of their policy preferences. By holding legislators accountable for their claims of a policy's benefits to futurity, legislators would better consider the needs of future generations in their political calculations.

38. Professors James Buchanan and Gordon Tullock have addressed the role of morality in policymaking:

Our quarrel with those who would rely primarily on the moral restraint of individuals to prevent undue exploitation of individuals and groups through the political process is ... at base an empirical one. The assessment of the nature of man himself will, or should, determine the respective importance that is placed on institutionalconstitutional restraint and on moral limitations on the behavior of individuals in political society.

JAMES M. Buchanan \& Gordon Tullock, The CAlculus of CONSENT: Logical Foundations of COnstitutional Democracy 305-06 (1962). This Note does not evaluate the more radical or more pragmatic proposals that have been voiced that in some way address the issues of intergenerational inequity. See, e.g., ROBYN ECKERSLEY, THE GREEN STATE: RETHINKING DEMOCRACY AND SOVEREIGNTY 111-12 (2004) (proposing a radical shift from liberal to "ecological democracy" in which "the opportunity to participate or otherwise be represented in the making of risk-generating decisions should literally be extended to all those potentially affected, regardless of social class, geographic location, nationality, generation, or species"); DANIEL A. FARBER, ECO-PRAGMATISM 9-11 (1999) (advocating a pragmatic "approach to environmental problems, in which economic analysis is useful, but not controlling").

39. This Note refers to this issue interchangeably as political short-termism or policy myopia. For a general introduction to this phenomenon, see Toke S. Aidt \& Jayasri Dutta, Policy Myopia and Economic Growth, 23 EUR. J. POL. ECON. 734 (2007); Iconio Garri, Political Short-Termism: A Possible Explanation (Università Cattolica del Sacro Cuore, Working Paper No. 48, 2007), available at http://www.unicatt.it/Istituti/TeoriaEconomica/Quaderni/itemq0748. pdf.

40. See Kristian Skagen Ekeli, Giving a Voice to Posterity-Deliberative Democracy and Representation of Future People, 18 J. AGRIC. \& ENVTL. ETHICS 429, 434 (2005) (advocating to reserve seats in legislative assemblies for future generation representatives). 


\section{THE PROBLEMS OF INTERGENERATIONAL INEQUITY AND POLITICAL SHORT-TERMISM}

Almost any newspaper clipping evinces the problem of intergenerational inequity; from climate change to failing schools, political leaders fail to adequately consider future interests in evaluating policy options. ${ }^{41}$ But this myopia is not the product of a lack of a concern for children or future inhabitants of Earth; instead, it is the result of institutional constraints that encourage political leaders to prioritize the short-term needs of voters. Such an institutional arrangement conflicts with a moral commitment to future generations. As President Lincoln pronounced:

$[W]$ e cannot escape history. We ... will be remembered in spite of ourselves. No personal significance or insignificance can spare one or another of us. The fiery trial through which we pass will light us down in honor or dishonor to the latest generation.... We, even we here, hold the power and bear the responsibility. ${ }^{42}$

This Part sets out the moral argument for a commitment to future generations and then moves on to examine how policymaking exacerbates intergenerational inequity and how the institutional configuration of liberal democracies promotes this result.

\section{A. The Merits of a Moral Commitment to Posterity}

Moral arguments for a commitment to future generations are plentiful and diverse. How society goes about defining its moral commitment is ultimately important in developing a legislative mechanism to represent future generations. This Section outlines some of the arguments for recognizing the interests of future generations.

Parents generally desire for their children to be happy and are willing to sacrifice to secure this happiness. ${ }^{43}$ The happiness of these children, in turn, depends on the happiness of their children, whose happiness depends on the happiness of their children, and so on down the family tree. People thus have an interest in their great-great-great

41. See infra Part I.B.

42. Abraham Lincoln, Second Annual Message (Dec. 1, 1862), in 7 A CoMPILATION OF THE MESSAgES AND PAPERS OF THE PRESIDENTS 3327, 3343 (James D. Richardson ed., 1897).

43. See Jan Narveson, Future People and Us, in Obligations to Future Generations 38, 57 (R.I. Sikora \& Brian Barry eds., 1978) ("Most people claim to desire a better lot in life for their offspring than themselves ...."). 
grandchildren's lives. But this argument does not explain why people should care about future generations rather than only their descendants.

Kantian ethics also promotes concern for future generations. Immanuel Kant's dictate-that humans be treated as ends in themselves and not merely as means ${ }^{44}$-includes posterity. Because human beings are inherently interested in achieving this ideal, ${ }^{45}$ "[t]hey have a duty to posterity simply because only posterity can realise that ideal."

John Rawls similarly advocates a moral obligation to future generations in A Theory of Justice, but his concern for posterity is more focused than Kant's, because he advocates passing on a greater amount of cultural capital than the present generation received from its ancestors. ${ }^{47}$ Rawls derives this belief from the notion that those in the "original position" "48 "are understood to belong to 'any' and 'all' generations." "49 Under Rawls' theory, "[e]ach generation must not only preserve the gains of culture and civilization, and maintain intact those just institutions that have been established, but it must also put aside in each period of time a suitable amount of real capital accumulation." ${ }^{50}$ This accumulation of capital would continue until a

44. Immanuel Kant, The Metaphysics of Morals 56 [Ak. 231] (Mary Gregor trans., Cambridge Univ. Press 1991) (1797); see also ImMAnuel Kant, Foundations of the MetAPHYSICS OF MoRALS 86 (Lewis White Beck ed. \& trans., Univ. of Chicago Press 1950) (1785) ("[E]very rational being exists as an end in himself and not merely as a means to be arbitrarily used by this or that will."). For a brief summary of Kant's ideal theory, see Sarah Williams Holtman, Kant, Ideal Theory, and the Justice of Exclusionary Zoning, 110 ETHICs 32, 35-39 (1999).

45. ImMANuel Kant, The Contest of Faculties, in POLITICAL Writings 176, 182 (Hans Reiss ed., H.B. Nisbet trans., 2d ed. 1991) (1970).

46. John Passmore, Conservation, in RESPONSIBILITIES to FUTURE GENERATIONS 45, 50 (Ernest Partridge ed., 1981).

47. Id. at 52 .

48. Rawls's "original position" is

a purely hypothetical situation characterized so as to lead to a certain conception of justice. Among the essential features of this situation is that no one knows his place in society, his class position or social status... his intelligence, strength, and the

like... The principles of justice are chosen behind [this] veil of ignorance.... Since all are similarly situated and no one is able to design principles to favor his particular condition, the principles of justice are the result of a fair agreement or bargain.

John RAwls, A THEORY OF Justice 11 (rev. ed. 1999). According to Rawls, just rules are those that would be chosen from the original position. $I d$.

49. Ernest DeAlton Partridge, Jr., Rawls and the Duty to Posterity (Aug. 1976) (unpublished Ph.D. dissertation, University of Utah) (on file with the Duke Law Journal).

50. RAWLS, supra note 48, at 252. 
steady state of just institutions has been reached. ${ }^{51}$ Thus, a generation's temporal position does not give it a moral claim over other generations' interests simply because the other generations come later. $^{52}$

A commitment to future generations also lines up with the theory of sustainability in environmental economics. ${ }^{53}$ Professor Edith Brown Weiss defines this norm in the following way:

The human species holds the natural and cultural resources of the planet in trust for all generations of the human species... This planetary trust obligates each generation to preserve the diversity of the resource base and to pass the planet to future generations in no worse condition than it receives it. Thus, the present generation serves both as a trustee for future generations and as a beneficiary of the trust. ${ }^{54}$

51. See Richard A. Epstein, Justice Across the Generations, 67 TeX. L. REV. 1465, 1465 (1998) (summarizing this phenomenon).

52. According to Rawls

[i]t is a natural fact that generations are spread out in time and actual economic benefits flow only in one direction. This situation is unalterable, and so the question of justice does not arise. What is just or unjust is how institutions deal with natural limitations and the way they are set up to take advantage of historical possibilities. Obviously if all generations are to gain (except perhaps the earlier ones), the parties must agree to a savings principle that insurers that each generation receives its due from its predecessors and does its fair share for those to come. The only economic exchanges between generations are, so to speak, virtual ones, that is, compensating adjustments that can be made in the original position when a just savings principle is adopted.

RAWLS, supra note 48, at 254; see also BRUCE ACKERMAN, SOCIAL JUSTICE IN THE LIBERAL STATE 203 (1980) ("[A]ll citizens are at least as good as one another regardless of their date of birth.").

53. See Edith Brown Weiss, The Planetary Trust: Conservation and Intergenerational Equity, 11 ECOLOGY L.Q. 495, 498 (1984) ("Our capacity to harm the environment globally forces us for the first time to be concerned at a global level with survival of the natural and cultural heritage that we pass to future generations.").

54. Id. at 498-99. Professor Brown Weiss further develops this planetary trust concept in her book, IN FAIRNESS TO FUTURE GENERATIONS: INTERNATIONAL LAW, COMMON PATRIMONY, AND INTERGENERATIONAL EQUiTY (1989), which has stimulated much debate, see, e.g., Paul A. Barresi, Beyond Fairness to Future Generations: An Intragenerational Alternative to Intergenerational Equity in the International Environmental Arena, 11 TUL. ENVT'L L.J. 59 (1997) (critiquing Weiss' argument); Edith Brown Weiss, A Reply to Barresi's "Beyond Fairness to Future Generations," 11 TUL. ENVT'L L.J. 89 (1997) (responding to Barresi's article); see also Chairman of World Comm'n on Env't and Dev., Our Common Future, at 24, delivered to the General Assembly, U.N. Doc. A/42/427 (Aug. 4, 1987) [hereinafter BRUNDTLAND REPORT], available at http://www.worldinbalance.net/pdf/1987-brundtland.pdf (offering another definition of "sustainability" as development that "meets the needs of the present without compromising the ability of future generations to meet their own needs"). 
There are also a number of arguments against awarding rights to or even recognizing the interests of future generations yet unborn. First, predictive capabilities erode as the predictor looks further into the future. ${ }^{55}$ Second, predictions about what the future will be like can be empirically falsified. ${ }^{56}$ Third, the number of individuals in any given future generation is indeterminate, and the existence of any given future individual is contingent upon many factors. ${ }^{57}$ Fourth, it is difficult to predict the needs and wants of future generations; the actual quantity of future persons is impossible to predict and thus utility calculations are fruitless exercises. ${ }^{58}$ Finally, society "cannot enter into an explicit contract with the community of the future",,${ }^{59}$ it cannot be sure which future generations will share its "altruistic impulses and fellow-feeling" and thus be "members of [its] moral community." ${ }^{60}$

Actual experiences have rebutted some of these arguments, such as society's capacity to make predictions. ${ }^{61}$ Others are not unique; that is, they "apply to cases that are both contemporary and morally significant (i.e., such features as unidentifiability, improbability, ignorance of number, ignorance of tastes and desires, and so on).",62 Although these arguments have some validity, future generations should still be considered and protected in present-day decisionmaking. Beyond the recognition of a moral commitment to future generations, however, the biggest hurdle to realizing a political

55. Ernest Partridge, Introduction, in ResPONSIBILITIES TO FUTURE GENERATIONS, supra note 46 , at 1,7 .

56. Id.

57. $I d$.

58. Id.

59. Martin P. Golding, Obligations to Future Generations, in RESPONSIBILITIES TO FUTURE GENERATIONS, supra note 46, at 61, 65.

60. Id. at 66 .

61. Technology, for example, aids society's predictive capabilities by allowing it to monitor and model the planet's environment. Thus

we are not totally blind to the consequences of the technical ventures now at work or contemplated. Our age has witnessed not only a revolution in power but also a revolution in communications and information processing. From satellites and worldwide recording and transmitting stations, we monitor the pulse of the planetary organism: the solar input, the hydrological and nutrient cycles, the climatic changes, the patterns of land use, and so on. We know what is happening; and, with new developments in computer modeling of complex integrated functions, we may be able to discover the graver hazards that lie in the path ahead, both for us and for our posterity.

Partridge, supra note 55, at 2.

62. Id. at 8 . 
order that respects posterity interests is a positive one-how and why future generations are not represented in political decisionmaking. The next Section thus details some of the ways in which future generations are not properly represented in policymaking processes.

\section{B. The Existence and Causes of Intergenerational Inequity}

Political action frequently does not match political rhetoric. "It's easy for people to feign concern for future generations and at the same time rip them off." ${ }^{, 3}$ And this problem is not unique to hurricanes and levees. Daily newspapers are awash with examples of this political "short-termism"- the failure of policymakers to adequately deal with long-term problems. ${ }^{64}$ Although there is some marginal concern for near future generations, "the future whispers while the present shouts. ${ }^{\circ 5}$ This results in an externality to future generations, ${ }^{66}$ creating intergenerational inequity ${ }^{67}$ and potentially long-run inefficiency. That is, present generations are given preferential treatment over future generations, which may be concerning from a distributive justice perspective or from an economic efficiency perspective.

The preference for present-generation interests over future interests is based on the observer. If one had no affiliation with the present, one would not prefer present benefits over future benefits.

63. Walter E. Williams, Caring About the Future, TownHALl.COM, May 15, 2002, http:// www.townhall.com/columnists/WalterEWilliams/2002/05/15/caring_about_the_future.

64. See, e.g., Do-Nothing Decade, Times-PiCAYUnE (New Orleans), Dec. 4, 2002, at B6 (climate change); Jed Graham, Delaying Social Security Reform Will Make Problems Far Worse, InVESTOR's Bus. DAILY, June 1, 2005, at A1 (social security); William C. Symonds, How to Fix America's Schools, BUS. WEEK, Mar. 19, 2001, at 66 (public education).

65. Al Gore, EARTH IN THE BALANCE 170 (1992). This does not mean that citizens are not at all concerned with the effects their actions will have on posterity. Voters and politicians often show sincere concern to their children and grandchildren. Ekeli, supra note 40, at 432 . The situation changes when focusing on more remote generations. Id. "In general, it seems to be much more difficult to achieve popular and political support for tough policies that will benefit the more distant future." Id.

66. See E. J. Mishan, The Economics of Disamenity, 14 NAT. RESOURCES J. 55, 56-58 (1974) (defining external effects or "spillover effects" as a situation in which "person A's utility function ... is affected by variables over which B, but not A, has control). For a response to the argument that these "externalities" are really just necessary investment costs for the upward trend in income per capita over time, see Jerome Rothenberg, Intergenerational Ethics, Efficiency, and Commitment, in DiscounTING AND INTERGENERATIONAL EQUiTY 103, 107 (Paul R. Portney \& John P. Weyant eds., 1999).

67. This phenomenon need not only be experienced by distinct sets of individuals but can also arise between present and future selves. 
American legislators, in contrast, have strong ties to the present and thus have strong incentives to avoid dealing with future problems. Thus, legislators do not deserve all the blame for their inaction. As rational political actors, they are only making choices that will promote their interests. "Because politicians are concerned with getting reelected, they have limited time horizons, leading them to "prefer policies that yield tangible benefits for constituents in the near term." ${ }^{\circ 8}$ A policy that will not ripen until after the next election (or worse, after the actor's political career) has about as much value as a bank note that will not mature until several generations after its holder's death. "[P]oliticians in democratic states, who are elected for relatively short periods and who are judged by voters largely in terms of the immediate results of their actions, also have strong incentives to overdiscount the future in the policy-making process." Consequently, their viewpoints are necessarily shortsighted, and future generations cannot intervene. "We act as we do because we can get away with it: future generations do not vote; they have no political or financial power; they cannot challenge our decisions." ${ }^{, 70}$ Anthony Downs's seminal work on the issue-attention cycle ${ }^{71}$ demonstrates that a politician's policy need only be effective-or give the promise of effectiveness-for so long as the public is interested in the issue.

Even if, down the road, the issue returns to the forefront of political conversation, blame for the failure to deal with the issue properly the first time is often misdirected at officials currently in power. $^{72}$ And if the public properly blames the responsible officials, these officials probably are no longer in power; ${ }^{73}$ they can no longer do anything about the problem. If the problem is to be solved, the question becomes who is going to deal with it this time around. Thus, American political society has grown accustomed to shirking the weightier problems of the day, putting the problems off to a later time

68. Ben Depoorter, Horizontal Political Externalities: The Supply and Demand of Disaster Management, 56 DuKe L.J. 101, 111 (2006) (quoting Richard A. Posner, CATASTROPHE 137 (2004)).

69. Gregory S. Kavka \& Virginia Warren, Political Representation for Future Generations, in ENVIRONMENTAL PHILOSOPHY 21, 28 (Robert Elliot \& Arran Gare eds., 1983).

70. BRUNDTLAND REPORT, supra note 54, at 24.

71. See Anthony Downs, Up and Down with Ecology: The 'Issue-Attention Cycle,' 28 PuB. INT. 38, 38 (1972) (noting that public attention may generate public pressure to effect change).

72. Id. at 47 .

73. Id. 
when the consequences for inaction are more immediate and the range of options is more limited.

This discussion does not suggest that the legislative process does not consider the interests of future generations. In fact, almost all cost-benefit analyses take future costs and benefits into consideration, irrespective of whether the costs and benefits will apply to presentgeneration constituents or prospective ones. ${ }^{74}$ Some might apply what economists call a discount rate, which compares the value of a future preference to the value of a present one..$^{75}$ But focusing on the question of how to arrive at the proper discount rate, as seems to be the concern of economists and legal scholars, ${ }^{76}$ ignores the larger question of how to get political actors to concern themselves with the costs and benefits to posterity and translate these concerns into policy preferences. The proper discount rate matters only if it is the one actually used to make-not just analyze-policy choices. In other words, if policymakers read a policy report with a zero discount rate-meaning that future preferences are weighed evenly with present ones (ignoring inflation) - but then effectively discount the future benefits in their policy actions, the discount rate is not controlling.

74. But this is only true for the policy analysis. The legislator is then free to determine the value to put on competing interests. Critical in this evaluation will be the way in which a cost or benefit is likely to affect the legislator's constituency.

75. For a fuller and more complete discussion of the economic principles behind discounting, see generally Geoffrey Heal, Discounting: A Review of the Basic Economics, $74 \mathrm{U}$. CHI. L. REV. 59 (2007). But at least one prominent report on climate change uses a discount rate of zero, meaning that a future person is valued the same as a present person. See NicHOLAS Stern, Stern Review: The Economics of Climate Change 31-33 (2006), available at http://www.hmtreasury.gov.uk./independent_reviews/stern_review_economics_climate_change/ stern_review_report.cfm ("We take a simple approach in this Review: if a future generation will be present, we suppose that it has the same claim on our ethical attention as the current one."); see also William Nordhaus, Critical Assumptions in the Stern Review on Climate Change, 317 SCIENCE 201, 201 (2007), available at http://nordhaus.econ.yale.edu/nordhaus_stern_science.pdf (concluding that the Stern Review's proposal to move up the timetable on emissions reductions as compared to other reports "stems almost entirely from its technique for calculating discount rates and only marginally on new science or economics").

76. See, e.g., Cass R. Sunstein \& Arden Rowell, On Discounting Regulatory Benefits: Risk, Money, and Intergenerational Equity, 74 U. CHI. L. REV. 171, 171 (2007) ("To be sure, costbenefit analysis with discounting can produce serious problems of intergenerational equity ...."). 


\title{
II. THE ENVIRONMENTAL ETHICISTS' POSTERITY-ORIENTED LEGISLATURES
}

\author{
The Preamble to the United States Constitution explicitly \\ references posterity:
}

We the People of the United States, in Order to form a more perfect Union, establish Justice, insure domestic Tranquility, provide for the common defence, promote the general Welfare, and secure the Blessings of Liberty to ourselves and our Posterity, do ordain and establish this Constitution for the United States of America. ${ }^{77}$

Some scholars have called for a larger role for the Constitution's Preamble in the Supreme Court's jurisprudence. ${ }^{78}$ The Court, however, does not consider the Preamble precedent. ${ }^{79}$ Still, because of its express reference to posterity, the Preamble seems the most appropriate starting place for institutional reform. ${ }^{80}$

The idea of political representation of future generations through the legislature is not new. ${ }^{81}$ There have been at least three calls for "some seats in a democratically elected legislative assembly ... to be reserved for representatives of posterity." ${ }^{82}$ The response, critical or

77. U.S. CONST. pmbl. (emphasis added).

78. See, e.g., Arthur S. Miller, Nuclear Weapons and Constitutional Law, 7 NovA L.J. 21, 27 (1982) ("The time has come to think seriously about giving substantive content to the preamble.”); Charlie Ogle, Executive Dir., Constitutional Law Found., Preamble: Relevance to Environmental Law: Does the United States Constitution Provide Environmental Protection?, Presentation at the L.A.W. Public Interest Law Conference at the University of Oregon (Mar. 7, 1998) (transcript available at http://www.conlaw.org/prearg2.htm) (arguing, in the context of environmental policy, that "the Preamble most clearly lays out the vision and wishes of the framers and adopters of the Constitution" and that "both the spirit and words of the Preamble direct our government to protect the interests of posterity").

79. See Jacobson v. Massachusetts, 197 U.S. 11, 22 (1905) ("Although th[e] Preamble indicates the general purposes for which the people ordained and established the Constitution, it has never been regarded as the source of any substantive power conferred on the Government of the United States or on any of its Departments.").

80. Professors James Buchanan and Gordon Tullock define a constitution as "a set of rules that is agreed upon in advance and within which subsequent action will be conducted." BUCHANAN \& TULLOCK, supra note 38 , at vii.

81. See Kavka \& Warren, supra note 69, at 21-39 (discussing "the question of political representation for future people").

82. Ekeli, supra note 40, at 430. This Note does not discuss a proposal made by Professor Dennis Thompson for a "Tribunate (for Posterity)," Dennis F. Thompson, Democracy in Time: Popular Sovereignty and Temporal Representation, 12 CONSTELlations 245, 256-57 (2005), because the approach is not developed well enough and it does not seem to be confined within a legislature, instead acting more like an independent commission. This Note also does not address related proposals to create age-differentiated political rights, proxy votes for children, 
confederate, has been fairly muted. ${ }^{83}$ This Part describes the three proposals of the individual proponents separately to showcase the range of forms a posterity-oriented legislature might take and to examine the progression of the proposal.

\section{A. Kavka and Warren's Proposal}

Professors Gregory S. Kavka and Virginia Warren were the first scholars to propose designating legislative representatives for posterity, although the two other proponents of that idea do not acknowledge their contribution. Writing together in a volume on environmental philosophy, Professors Kavka and Warren begin with the premise that future generations are not represented in the present-generation political conversation. ${ }^{84}$ They then move on to the normative question of whether future generations ought to be represented, concluding that

because the choices which democratic societies make now have enormous impact on future generations, and because we collectively know this and can make better than random guesses about the long-

or policies that encourage reproduction, all which would increase the proportion of children in the voting population and thereby lessen the disproportionate impact older voters have in political decisions. See Philippe Van Parijs, Rawls and Machiavelli: The Dream Team? (June 1998) (unpublished manuscript, on file with the Duke Law Journal) (discussing these proposals).

83. See Kavka \& Warren, supra note 69, at 21 (noting that even normative theories focus on current interests, ignoring future people's interest). Commentators have invoked the futureoriented legislature proposals, however, in discussions of deliberative democracy. E.g., AMY GutMANN \& DENNIS THOMPSON, DEMOCRACY AND DISAGREEMENT 155-63 (1996) (discussing "several different responses to the problem of representing future generations"); Hans von Rautenfeld, Thinking for Thousands: Emerson's Theory of Political Representation in the Public Sphere, 49 AM. J. POL. SCI. 184, 191 n.8 (2005) ("Thompson lists possible constituencies for elected representatives: the nation, a political party, the district as a whole, the electoral majority in the district, and individuals who make direct appeals. This list is expanded in Gutmann and Thompson to include future generations." (citations omitted)).

Part of the explanation for the lack of exploration of future-generation representation is that this subject lies at the crossroads of numerous academic disciplines. See Wolfe, supra note 30. Even when commentators are willing to take this problem head-on, a chasm remains between the different disciplines. Ethicists argue why society should care for future generations and even offer the mechanisms for this intergenerational altruism. Social scientists explain why these preferences, when present, are muted in the traditional political landscape. But far less attention has been paid to reshaping political institutions to better contemplate these long-term preferences and thus to recognize the interests—and value-of future generations.

84. Kavka \& Warren, supra note 69 , at 21. 
range outcomes of different choices, it is appropriate at this time to raise the question of political representation for future people. ${ }^{85}$

Their proposal begins by responding to the theoretical objection ${ }^{86}$ that a present-generation party cannot represent future generations. ${ }^{87}$ Citing legal examples of attorneys representing those without the ability to express their interests, such as deceased persons or unborn trust beneficiaries, Professors Kavka and Warren argue that the only precondition of representation is that the represented "hav[e] interests ... capable of faring well or faring ill" at some point along the time continuum. ${ }^{88}$ Regarding the concern of the inability to represent the interests-with certainty-of those not yet born, the proposal assumes the representative need only "know enough about the likely interests of the represented party and the means of promoting those interests, to be able to make better than random judgments about how alternative policies are likely to affect the interests of the represented party."

Finally, the article addresses some of the practical objections to setting aside legislative seats for posterity interests, admitting that "[i]t is likely to seem unacceptable to most people because it is novel, sounds radical, has never been tried anywhere, and because it is not clear how or whether it would work if put into practice." ${ }^{90}$ In response to its critics, the article lays out a concrete method by which a handful of representatives in each chamber of Congress could serve the interests of future generations: these representatives would advocate posterity interests by performing the same tasks as any other representative. ${ }^{11}$ The article proposes that presidential appointment or national election would choose the future representatives. ${ }^{92}$

\footnotetext{
85. Id. at 22 .

86. See supra notes 55-60 and accompanying text.

87. Kavka \& Warren, supra note 69 , at 22-23.

88. Id. at 23-24 (emphasis omitted).

89. Id. at 25. The proposal also addresses the concern of including future generations in the political process when so many other articulable groups or interests are still overlookedspecifically, children, later selves, past citizens, and foreigners. Id. at 26-33. It concludes that these interests are distinguishable from future generations. $I d$.

90. Id. at 34 .

91. Id.

92. Id. at 34-35.
} 


\section{B. Dobson's Proposal}

Unlike Kavka and Warren, who advocate for future generations over other unenfranchised groups, ${ }^{93}$ Andrew Dobson frames his proposal within the general goal of promoting political representation of all unrepresented interests. ${ }^{94}$ As such, his article discusses the representation-its democratic nature and specific design-of three constituencies "that render problematic current understandings of the way representative democracies should function": nonnationals; future generations; and "other species," which might range from nonhuman animals to the natural environment. ${ }^{95}$

In his section on future generations, Dobson quickly dismisses the objections to the political recognition of future people and their interests. "The big problem, though, is that future generations cannot vote and can provide no representatives." 97 Therefore, he proposes drawing proxy or substitute future generations from the present generation. ${ }^{98}$ This proxy would serve as the electorate and candidates would be drawn from it. ${ }^{99}$ As for who would comprise this proxy future electorate, he proposes two options: (1) a random sample of present generation voters; or (2) a lobbying group in the present generation that is concerned about future generations, such as the environmental sustainability lobby. ${ }^{100}$ The first option would provide "no guarantee that the interests of future generations would in fact be represented by such a random sample," potentially leading to present generations favoring their own interests when they conflict and using the extra clout to serve their own needs. ${ }^{101}$ He thus favors the second option, ${ }^{102}$ even at the expense of the democratic ideal of keeping political power in the hands of ordinary people and out of the hands of experts. ${ }^{103}$ According to Professor Dobson, sacrifice of this

\footnotetext{
93. Id. at $26-33$.

94. Andrew Dobson, Representative Democracy and the Environment, in DEMOCRACY AND the EnVIRonment: Problems AND Prospects 124, 124 (William M. Lafferty \& James Meadowcroft eds., 1996).

95. Id. at 124-25.

96. Id. at $131-32$.

97. Id. at 132 .

98. Id. at 132-33.

99. Id.

100. Id.

101. Id. at 133 .

102. Id. at 133-34.

103. Id. at 134 .
} 
particular ideal is justified because it is the only way to adequately represent future generations and because it will provide the proxy electorate with candidates who will actually represent future generations. ${ }^{104}$ Professor Ekeli later terms Dobson's approach the "restricted franchise model" because it does not offer all voters the right to elect F-representatives, instead reserving voting rights to present-generation proxies for future generations. ${ }^{10}$

Next, Dobson addresses the concern that the environmental sustainability lobby, in advocating population growth measures, might actually reduce the number of those they are supposedly representing. ${ }^{106} \mathrm{He}$ responds that (1) environmentalists disagree on population growth and that their disagreement would play out in a healthy democratic forum, and (2) future generations "will at least be in favour of policies that guarantee them the environmental conditions within which to exercise their political autonomy." ${ }^{107}$ As to how future interests would be analyzed, he quickly dismisses discounting because "there is no discernible reason for regarding future human beings as any less equal than present ones, in which case representing their interests indirectly through present generation sympathizers amounts to an injustice."108

\section{Ekeli's Proposal}

Building off of Dobson's model, Professor Ekeli proposes a more expansive version of posterity representation in the legislature. ${ }^{109} \mathrm{He}$ justifies this model with general concern that deliberative democracy is illegitimate without posterity's voice and without the added value the representations of future generations would bring to policy decisions. ${ }^{110}$ Specifically, Professor Ekeli proposes that "some seats in the legislative assembly (for instance 5 percent) should be reserved for future generation representatives."111 The general voting populace would elect these future-generation representatives (F-

\footnotetext{
104. See id. at 133 (suggesting that a lobbying group will present "a real range of options to choose from and therefore the alternatives, in the guise of proxy candidates, necessary for accountability to be meaningful will be available“).

105. Ekeli, supra note 40, at 434-35.

106. Dobson, supra note 94 , at 133 .

107. Id. at $133-34$.

108. Id. at 135.

109. Ekeli, supra note 40, at 430-31.

110. Id.

111. Id. at 434 .
} 
representatives), who would then function as ordinary legislators. ${ }^{112}$ With each voter having two votes-one for the presentrepresentatives and one for the F-representatives-the candidates would attempt to sway them by "present[ing] the ends and means they will advocate in the legislative assembly so that the electorate would have the opportunity to consider their political programs."113

In addition to these requirements, Professor Ekeli would allow a supermajority of F-representatives to delay, but not block, a proposal for some period of time or until elections occur. ${ }^{114}$ Professor Ekeli offers three reasons in support of his "extended franchise model": (1) expertise about future-oriented issues will improve the public dialogue, (2) F-representatives will serve as stewards of future generations in present political decisionmaking processes, and (3) political institutions will be more future oriented. ${ }^{115}$

All three sets of proposals share the common idea that future generations should be represented in a legislature by representatives elected solely to identify and stand for their interests. The core idea is similar to agency delegation in that it encourages consideration of future interests; it even more closely resembles the notion of posterity standing in that the future can be represented by present delegates.

\section{CRITIQUING ENVIRONMENTAL ETHICISTS' \\ Proposal And Suggesting A Potential Alternative}

Section A begins by critiquing the environmental ethicists' proposal to create a posterity-oriented legislature. Section B then uses these lessons as a springboard to propose a different way to encourage legislators to consider posterity's interests. It advocates creating a performance-based pension system that rewards (and punishes) legislators for policy choices based on the long-term outcome of those choices and how those choices are predicted to affect the future.

\footnotetext{
112. Id.

113. Id.

114. Id.

115. Id. at 441 .
} 


\section{A. The Promise and Shortfalls of the Environmental Ethicists' Posterity-Oriented Legislatures}

This Section critiques the idea of posterity-oriented legislatures, which have largely avoided review. ${ }^{116}$ It first addresses several major questions regarding posterity-oriented legislatures. These questions range from how many F-representatives to elect to how to hold these representatives accountable. It then addresses some of the potential political effects, both discursive and instrumental, that might result from implementing posterity-oriented legislatures.

1. Theoretical and Practical Concerns. Many of the concerns with F-representatives depend on how they would be structured. There are a number of theoretical and practical questions.

a. The Number of Representatives to Be Apportioned to Future Generations. What is the proper role of discounting the political equality of future generations? If the representative is truly representing all future generations and not just one future generation, the claimed constituency will dwarf the present-generation constituency. ${ }^{117}$ Given the massive size of this future-generation constituency, there must be a compromise between the desire to give future generations political equality with present generations and the desire to ensure that present generations retain a political voice. Such a compromise might employ a type of discounting so that "[future] representatives in present parliaments will be many fewer in number than the numerical weight of their interests would warrant." ${ }^{118}$ On the other hand, an inadequate apportionment of F-representatives would continue to prevent future generations from having any opportunity to influence policy or even block potentially harmful decisions. ${ }^{119}$ If a compromise cannot be reached that balances the intergenerational competition of political power, the model becomes untenable. ${ }^{120}$

b. F-Party Membership. Professor Ekeli proposes that future parties (F-parties) would be able to put forward F-candidates, and

116. But see id. at 434-35 (critiquing Dobson's model).

117. Dobson, supra note 94, at 135; Ekeli, supra note 40, at 442.

118. Dobson, supra note 94 , at 135.

119. Ekeli, supra note 40, at 442.

120. Id. 
these F-parties' establishment would be regulated by "inclusive" norms, which would incorporate diverse viewpoints but would also prevent powerful interest groups from exploiting the system. ${ }^{121}$ In a footnote, Professor Ekeli refuses to define the legal standard for Fparty membership, instead passing that question to "democratically elected legislators." 122 But Professor Ekeli seems to trust the very same legislators whose political livelihoods depend on currentgeneration voters and who cannot resist the coercive influence of special interest groups. If legislators were allowed to define the legal standard for these parties, they would likely do so with these constituencies in mind.

Under Professor Ekeli's model, in addition to these interest groups, present-generation political parties also would be excluded from the list of eligible F-parties to prevent duplicity. ${ }^{123}$ From the statements made in the three proposals, ${ }^{124}$ it seems that only those that lack sufficient influence in the traditional regime, such as perhaps the sustainable development lobby, would be eligible to establish Fparties. But if only the disenchanted are allowed to form these Fparties, they might seize this opportunity to represent their own short-term needs. ${ }^{125}$ A system in which present-generation voters could directly choose these F-representatives would increase accountability and democratic legitimacy but also decrease the possibility of enfranchising the disenfranchised.

c. F-Representatives' Electorate. Professor Ekeli argues that Professor Dobson's model is countermajoritarian because it allows certain elites to have twice the number of votes as the rest of the

121. Id. at $437-38$.

122. Id. at 438 n.11. Ekeli also states that these norms would be enforced by judicial review, although he admits the paradox of giving unelected judges this discretion to make the law. Id. at 438.

123. Id. at $438-39$.

124. See supra Part II.

125. The value of having agencies do the cost-benefit analysis is that special interest groups cannot as easily influence the administrative rulemaking process. The price of the insulation from special interest is a loss of direct accountability in having unelected officials develop policies. There is still, however, a possibility of the regulated industry exerting control over the regulatory process-agency capture. See MAncur Olson, The LOgiC OF COLlective ACTION 3 (2d ed. 1971) (providing the classic definition of agency capture); see also JeanJacques Laffont \& Jean Tirole, The Politics of Government Decision-Making: A Theory of Regulatory Capture, 106 Q.J. ECON. 1089, 1094 (1991) (developing a model that evaluates the role of interest-group power and agency politics on the extent of agency capture). 
electorate. ${ }^{126}$ Dobson suggests that a lobbying group or even a random sample of the population should elect the F-representative. ${ }^{127}$ This method, Professor Ekeli argues, would violate the historic and constitutional concept of voting power equality. ${ }^{128}$

Professor Ekeli's model solves this problem by giving everyone two votes: one for a present-representative and one for a future representative. ${ }^{129}$ Although this approach maintains political equality, it assumes that present generations will somehow be able to distinguish future-oriented concerns from their own short-term needs. The notion that present-generation voters will elect representatives who are concerned with future interests, without further restraint on the voters or the representative pool, is a fiction because voters tend to discount long-term benefits in favor of short-term ones. ${ }^{130}$

Even if the F-representatives were not at all concerned about present public opinion, it would be irresponsible for F-representatives to support legislation unlikely to garner "public support over the long haul," as the scheme probably would not achieve the goals of the legislation if future generations then excised it. ${ }^{131}$ Because it is unlikely that voters would opt for future over present needs, without some incentive, Professor Ekeli's proposal would monitor the election of F-representatives so that the choice would be between the greater of two goods. But this choice is dependant on the quality of candidates running to be F-representatives.

d. The F-Representatives. If the electoral system limits the candidacy of F-representatives to individuals with certain qualities (Dobson, for example, might limit candidacy to the sustainable

\footnotetext{
126. Ekeli, supra note 40, at 435.

127. Dobson, supra note 94 , at 132-33.

128. See Gray v. Sanders, 372 U.S. 368, 381 (1963) ("The conception of political equality from the Declaration of Independence, to Lincoln's Gettysburg Address, to the Fifteenth, Seventeenth, and Nineteenth Amendments can mean only one thing-one person, one vote."); Ekeli, supra note 40, at 434-35 (describing Dobson's model as one of "restricted franchise" because the environmental sustainability lobby elects the F-representatives). Dobson's model would give some members of the electorate more than one vote and thus violate the "one person, one vote" rule. See Gray, 372 U.S. at 381 (laying out the rule).

129. Ekeli, supra note 40, at 434.

130. See SAmuel Merrill \& Bernard Grofman, A Unified Theory of Voting: Directional AND PROXIMITY SPATIAL MODELS 130 (1999) (describing "the Grofman discounting model in which voters evaluate candidates by proximity but only after discounting their claims or their capacity to move the status quo to their preferred policy position").
}

131. FARBER, supra note 38 , at $153,157$. 
development lobby ${ }^{132}$ ), it would have to judge which type of ideology best represents posterity. ${ }^{133}$ The problem with this solution is that it mutes public discourse on how best to solve future-oriented problems and gives one particular lobbying group a tremendous amount of influence. ${ }^{134}$ As Professor Ekeli notes,

[e]nvironmental organizations not only make special claims to care about posterity, but also express particular views on what this involves-views that are open to debate. They normally assume that some form of environmental protection best realizes the interests of future generations, where their more technologically optimistic opponents might claim that this will not serve future interests at all. Much of the debate between environmentalists and their opponents is not about whether we should be concerned about future generations, but how we should meet their interests. Environmentalists represent just one strand in that debate. ${ }^{135}$

In addition to the problem of drawing F-representatives from a particular candidate pool, these F-representatives might also begin to share the same short-term political concerns fatal to presentgeneration legislators. In response to the concern that Frepresentatives will spend their time in office pandering for votes in the next election, Professor Ekeli considers limiting F-representatives to one term in office although he ultimately rejects the term-limit. ${ }^{136}$ But this would not solve the problem, because voters would simply shift their retrospective voting behavior from candidate centered to party centered. ${ }^{137}$ Furthermore, this would undermine any accountability that installing F-representatives in the legislature would offer.

e. Considerations of F-Representatives. As Professor Ekeli notes, determining what should be done about the future is based on shaky and controversial evidence, such as questions of what values to consider and how much weight to give those values, and difficult

132. Dobson, supra note 94 , at 133.

133. See Ekeli, supra note 40, at 436 (describing a system in which the electorate is forced to vote for candidates that are the most likely to promote the interests of future generations).

134. Id.

135. Id. (footnote omitted).

136. Id. at $439-40$.

137. See John H. Aldrich, Why Parties? The Origin and Transformation of POLITICAL PARTIES IN AMERICA 48-50 (1995) ("The candidate's party affiliation . . . provides a very inexpensive way to infer a great deal ....”). 
moral and political concepts. ${ }^{138}$ But this might be a reason to prefer Frepresentatives. The uncertainty associated with considering future interests may be more palatable in a legislative setting that sometimes requires soft decisions.

As to the extent to which society should weight the interests of posterity, ethicist Daniel Callahan offers the following possibilities:

a. Do nothing which could jeopardize the very existence of future generations.

b. Do nothing which could jeopardize the possibility of future generations exercising those fundamental rights necessary for a life of human dignity.

c. If it seems necessary, in the interests of the existing rights of the living, to behave in ways which could jeopardize the equivalent rights of those yet to be born, do so in that way which would as far as possible minimize the jeopardy.

d. ...[C]alculate... whether an act with uncertain consequences would be harmful to one's own children. If you would not conjure up the possibility of magical solutions occurring to save your own children at the last moment from the harmful consequences of your gambling with their future, do not do so even with future generations. ${ }^{139}$

The choice of norms greatly affects the outcome and effectiveness of the proposal.

f. Holding F-Representatives Accountable. The value of having F-representatives in a legislature is that they might be accountable to the interests of posterity. Without this accountability, the ability of Frepresentatives to effectively represent future interests breaks down.

In his classic text, Professor H.B. Mayo simplifies the concept of democratic representation to three simple requirements. ${ }^{140}$ Democratic representation exists when there are "(a) legislators (or decision-makers) who are (b) legitimated or authorized to enact public policies, and who are (c) subject or responsible to public

138. Ekeli, supra note 40, at 437.

139. Daniel Callahan, What Obligations Do We Have to Future Generations?, in RESPONSIBILITIES TO FUTURE GENERATIONS, supra note 46, at 73, 83-84.

140. H.B. MAYo, An INTROdUCTION To DEMOCRATIC THEORY 103 (1960). 
control at free elections." ${ }^{141}$ The problem for the posterity-oriented legislature proposal is that those whose interests the decisionmaker is representing are not the same as those who are holding the representative accountable. If that is so, are the representatives only representing the current interests of those who elect and reelect them?

2. Mixed Ex Ante Political Effects. Additionally, implementing a posterity-oriented legislature likely would have drastic and difficultto-predict implications for the traditional political process. This Section describes what some of these effects might be.

First, the presence of a posterity-oriented legislature with its Frepresentatives might enhance the political conversation by forcing discussion of future-oriented issues. ${ }^{142}$ The double vote-voting once for a present-representative and once for an F-representative-would "promote more regular public debate about environmental problems in general and issues affecting the near and distant posterity in particular." This might prove effective because "there is considerable evidence that people's preferences and perspectives change in response to inputs of additional information-particularly during political campaigns. If these assumptions are correct, the double-vote can make the interests and needs of future generations more 'imaginatively present' in the minds of the voters."

Implementing F-representatives might also affect presentoriented legislators and their strategy. Many legislators rely on the ability to point fingers at previous administrations or regimes to deflect criticism. ${ }^{145}$ Their related ability to defer action on important policy issues that affect future generations functions as a political externality, "the ability of some groups to use the power of government to transfer benefits to themselves without being forced to

\footnotetext{
141. Id.

142. See John Ferejohn, Instituting Deliberative Democracy, in DESIGNING DEMOCRATIC INSTITUTIONS 75, 98 (Ian Shapiro \& Stephen Macedo eds., 2000) ("Reforming electoral institutions to ensure a broader representation of views within legislatures would ... make public deliberation more informative to nonparticipants.").

143. Ekeli, supra note 40, at 440.

144. Id.

145. See, e.g., Depoorter, supra note 68, at 116-17 (describing how public officials used the "blame game" following Hurricane Katrina to reduce political accountability).
} 
pay compensation to the losers." ${ }^{146}$ Thus, bringing the generations into the same time space would force legislators to address futuregeneration issues head-on. ${ }^{147}$

At the same time, there is also a risk that F-parties and their representatives will take on too great an influence in parliamentary politics. If introducing F-representatives prevents either one of the major political parties from garnering a governing majority in the legislatures, these present-generation parties may be forced to form coalitions with a minority F-party or parties, thus making the Fparties kingmakers. ${ }^{148}$ This is a common scenario in countries that have proportional-representation voting systems that lead to multiparty legislatures. ${ }^{149}$ If this were to occur, it might actually give the F-parties too much power and upset the previously agreed-on balance between present and future interests.

Finally, present generations may be more carefree and assume that posterity's interests are represented elsewhere, thus excluding those interests from their decisionmaking calculus. If this occurs, then posterity-oriented legislatures have the perverse effect of making policies less attractive to posterity. In this situation, Professor Ekeli's dependence on the deliberative democracy model ${ }^{150}$ would actually hurt posterity by giving decisions added legitimacy because of the supposed representation of future generations.

There are real limits on the extent to which present generations are willing to relinquish power to future generations. Even if present generations are somewhat interested in looking out for future

146. Todd J. Zywicki, Baptists?: The Political Economy of Environmental Interest Groups, 53 CASE W. ReS. L. REv. 315, 320 (2002); see also Depoorter, supra note 68, at 108-10 (extending political externalities to the relationship between political actors across different levels of government).

147. See Depoorter, supra note 68, at 119 (describing these "political accountability deadweight losses").

148. See Pippa Norris, Choosing Electoral Systems: Proportional, Majoritarian and Mixed Systems, 18 INT'L POL. SCI. REV. 297, 310 (1997) (“[P]roportional elections can produce indecisive outcomes, unstable regimes, disproportionate power for minor parties in 'kingmaker' roles, and a lack of clear-cut accountability and transparency in decision-making.").

149. Wolfgang C. Müller \& Kaare Strøm, Coalition Governance in Western Europe: An Introduction, in COALITION GOVERNMENTS IN WESTERN EUROPE 1, 1 (Wolfgang C. Müller \& Kaare Strøm eds., 2003) ("Multi-party politics has become the twentieth-century norm. And inmulti-party systems... the possibility always exists that no party alone will command a parliamentary majority. Indeed, that possibility has become the rule, rather than the exception, in the majority of the world's parliamentary systems.").

150. See Ekeli, supra note 40, at 442-47 (evaluating proposals for the representation of future generations from the point of view of the deliberative democracy doctrine). 
generations, a free-rider problem would result. Not only would one be better off if a previous generation started implementing this value, one would be worse off if one's own generation began this trend. ${ }^{151}$ Therefore, no generation would have an incentive to incorporate this system and, if implemented, every generation would have an incentive to shirk its duty to future generations. The future generation cannot force the present generation to consider its interests any more than the present generation can punish past generations for not considering its interests.

\section{B. An Alternative Proposal: Tying Policy Outcomes to Legislators' Pensions}

One way of addressing the problem of policy myopia and indifference toward future generations is to affect the decisional calculus of policymakers. Legislators normally are motivated to provide constituency services and to vote on legislative proposals in ways that assure their reelection. ${ }^{152}$ As such, even an ideological claim of looking out for posterity interests will succumb to the short-term political realities. ${ }^{153}$ Incumbents not seeking reelection or without a competitive challenger may have somewhat greater autonomy over policy choices, but they still have no incentive to represent future generations.

The proposal laid out in this Section gives incumbents that incentive. Members of Congress continue to enjoy a fairly generous pension plan. ${ }^{154}$ A National Taxpayers Union Foundation study

151. Consider the creation of a pension system. If retirees receive benefits without having to pay into the system, they are unjustly enriched. If the program abruptly stops-or becomes insolvent-members of the labor force have paid into the system with no corresponding benefit. A posterity-oriented legislature creates this same unfairness on the front end and the back end, but only in reverse (that is, past generations pay the benefits, and present generations pay into the system for future generations).

152. This focus on the short term can create poor results in the long run:

Inattention and ignorance cause voters to notice (and oppose) only those policies that would impose large, direct short-term costs. Unfortunately, such policies ... may benefit the general public in the long term, and an officeholder's responsiveness to these narrow concerns serves the official's reelection imperative more than the public's interests.

John Gastil, By Popular Demand: Revitalizing Representative Democracy THROUgh DeLIBERATIVE Elections 3 (2000).

153. See supra Part I.B.

154. Patrick J. Purcell, Cong. Research Serv., Retirement Benefits for Members of Congress 1 (2007); see also Peter J. Sepp, Congressional Perks: How the Trappings of Office Trap Taxpayers, NAT'L TAXPAYERS UNION FOUND., Nov. 1, 2000, 
estimates that the Congressional pension plans are two to three times more generous than plans of similarly situated employees in the private sector. ${ }^{155}$ These plans are a benefit that does not depend on the manner in which a member of Congress served. ${ }^{156}$ As of 2007, even members convicted of most types of felonies still qualified for the pension plan. ${ }^{157}$

This Note proposes an alternative that would change the pension system by tying the pension payments to the outcomes-or the more refined projections - of policies developed, sponsored, or voted for by the legislator while in office. Although measuring the performance of a legislator may be imperfect, it would be possible to create metricsspecific measures by which to judge the long-term effectiveness of a particular policy initiative ${ }^{158}$-for the policy itself and thus reward (or punish) the proponents (or opponents) of the particular bill. Politicians frequently embed accountability mechanisms into their policies ${ }^{159}$ under this proposal, they would be holding themselves accountable rather than other actors.

http://www.ntu.org/main/press.php?PressID=343\&org_name=NTUF (describing the "perk[s]" that members of Congress enjoy by virtue of their pension plan); Allen Wastler, Congress' Pension: Nice and Secure, CNNMONEY.COM, Jan. 20, 2006, http://money.cnn.com/2006/01/20/ commentary/wastler/wastler/index.htm (describing the generosity of Congress' pension plan).

155. Sepp, supra note 154 .

156. PURCELL, supra note 154 , at $1-2$.

157. See 5 U.S.C. $\$ 8312$ (2006) (listing felonies that disqualify government employees from retirement benefits); PURCELL, supra note 154, at 13 ("Section 8312 of Title 5 provides that a federal employee, including a Member of Congress, may not receive a retirement annuity for any period of federal service if that individual is convicted of certain offenses that were committed during the period of service when the annuity was earned. In general, the crimes that would lead to forfeiture of a federal retirement annuity under this provision of law are limited to acts of treason and/or espionage."); see also Drew Griffin \& Kathleen Johnston, Pensions for Convicted Lawmakers Draw Watchdogs' Ire, CNN.COM, Jan. 6, 2007, http://www.cnn.com/2007/ POLITICS/01/03/congressional.pensions/index.html?eref=rss_topstories (recounting the efforts of two dozen watchdog groups to "stop making taxpayers pay the pensions of lawmakers who are convicted of or plead guilty to crimes committed while in office").

158. Professor Thompson suggests something similar, called "[p]osterity [i]mpact [s]tatements," which would "justify[] any adverse effects their actions might have on the democratic capacities of future sovereigns ... [and] show that [the Government's] actions were necessary to implement the will of a current majority, and that no other actions less restrictive of future majorities could achieve this end at reasonable cost." Thompson, supra note 82, at 257.

159. See, e.g., Federal Funding Accountability and Transparency Act of 2006, Pub. L. No. 109-282, 120 Stat. 118 (to be codified at 31 U.S.C. $§ 6101$ note); No Child Left Behind Act of 2001, Pub. L. No. 107-110, 115 Stat. 1425 (2002) (codified as amended primarily in scattered sections of 20 U.S.C.); Amtrak Reform and Accountability Act of 1997, Pub. L. 105-134, 111 Stat. 2570 (codified as amended in scattered sections of 49 U.S.C.); Health Insurance Portability Act of 1996, Pub. L. No. 104-191, 110 Stat. 1936 (codified in scattered sections of 26, 29 and 42 
Every individual vote could be essentially converted into a futures commodity. Voting for or against a bill would entail the same cost initially. The price of this commodity would then fluctuate based on the likelihood of reaching the policy's embedded expectations. These futures contracts could be traded freely among both current and former legislators to ensure that the price is a fair predictor of the expectations. If, for example, Policy A was up for a vote, purchasing a "yea" vote would cost $\$ 100$ and purchasing a "nay" vote would cost $\$ 100$. Policy A would include in the statutory language a set of longterm expectations and metrics by which to measure these expectations or some other proxy for the predicted impact of the policy. As time passed, the "yea" and "nay" vote commodities for Policy A would change in value, depending on the likelihood of these expectations being realized. If Policy A was a cap-and-trade program that successfully reduced carbon emissions consistent with expectations, then the "yea" vote would be worth more, and legislators that had this vote in their portfolios would ultimately receive larger pension payments. Conversely, those that opposed this bill would see a corresponding decrease in the value of their portfolio.

The initiation of a future commodities contract could only occur during the legislative vote to prevent legislators from waiting to see the policy's impact before determining what type of contract to purchase-a "yea" contract or a "nay" contract. But legislators could trade or buy other legislators' contracts. They might even be bundled so that consistent votes on similar policies would share the same market and thus improve fluidity. The legislature might also determine how much value each initial vote should have and whether the purchase price should vary depending on the importance of the policy being discussed.

This proposal might initially seem a far-fetched scheme, but a similar experimental market already exists in the Iowa Electronic Market (IEM). ${ }^{160}$ The IEM "is a real-money, small-scale futures exchange in which the ultimate values of the contracts traded are

U.S.C.); Personal Responsibility and Work Opportunity Act of 1996, Pub. L. No. 104-193, 110 Stat. 2105 (codified as amended in scattered sections of 8 and 42 U.S.C.); Government Management Reform Act of 1994, Pub. L. No. 103-356, 108 Stat. 3410 (codified as amended in scattered sections of 31 U.S.C.). Additionally, Justice White's dissenting opinion in INS $v$. Chadha, 462 U.S. 919 (1983), listed more than fifty statutes in which Congress used a legislative veto to check administrative agency discretion, $i d$. at 1003-13 (White, J., dissenting), a practice that the Court held unconstitutional in Chadha, id. at 959 (majority opinion).

160. Iowa Electronic Markets, http://www.biz.uiowa.edu/iem/ (last visited Apr. 31, 2008). 
determined by political events, financial events and economic indicators." ${ }^{, 161}$ Like a real market, investors use their own money to trade listed contracts for loss or profit. ${ }^{162}$

Each contract to be listed on the IEM is defined in terms of a name (to uniquely identify the contract), a "fundamental" on which the contract is based, an expiration date, and a liquidation value. The fundamental consists of some statistic or set of statistics which can be objectively measured, and the liquidation value will depend upon the value of the fundamental on some pre-specified date. Typically, each contract will be part of a set of contracts, and all contracts in a set will be based on the same fundamental. ${ }^{163}$

This Note's proposal would function similarly; the "fundamental" would be the set of expected outcomes embedded in the legislation and those opposing the legislation would function as the other side of the contract. There might also be a way to structure legislation so that if it is a revenue-generating activity (like building a toll road), legislators could earn a percentage of the proceeds.

The system would not be mandatory; instead, legislators could opt in. But with such an arrangement, legislators could translate their rhetorical concern for future interests ${ }^{164}$ into expectations of what their policies will do for these future generations. From these expectations, the legislators could then determine what the consequences to their pensions would be if the policies do or do not meet these expectations.

Some legislative initiatives would likely extend beyond a given legislator's career. Even if initiatives such as these were still ongoing when a legislator retired, the likelihood of future effectiveness could still be gauged to some extent and the past policy action valued accordingly. Thus, political accountability would extend even beyond the legislators' retirement. Finally, there may be constitutional problems to this proposal, such as legislative entrenchment, ${ }^{165}$ that would require a constitutional amendment for resolution.

\footnotetext{
161. Iowa Electronic Markets, IEM Basics: What Is the IEM?, http://www.biz.uiowa.edu/ iem/trmanual/IEMManual_1.html\#What (last visited Apr. 31, 2008).

162. Id.

163. Iowa Electronic Markets, Objects Traded in the IEM: What's Traded, http://www.biz. uiowa.edu/iem/trmanual/IEMManual_2.html\#What (last visited Apr. 31, 2008).

164. See supra text accompanying notes 20-24.

165. See Fletcher v. Peck, 10 U.S. (6 Cranch) 87, 135 (1810) (“[O]ne legislature is competent to repeal any act which a former legislature was competent to pass; and ... one legislature
} 
This proposal is not a silver bullet. For example, although it would be unnecessary to decide ahead of time how much weight to give future interests, the extent to which future outcomes affected legislators' pensions would implicitly create a discount rate. Thus, present-generation representatives would have to determine the value of the future-generation benefits in the accountability system. But there determination would be transparent.

On balance, this proposal more ably addresses or avoids the concerns laid out for posterity-oriented legislatures. First, it would not need to decide F-parties or F-voters - and thus no double-voting issue would present itself-because the traditional electoral system remains intact. What would-hopefully-change is the political discourse. Considerations of future interests would not merely be a legislative issue; they would become a campaign issue. How candidates consider future interests and to what extent they factor into issue positions would affect the present-generation electorate's voting behavior. But instead of relying on inflated rhetoric, voters would base decisions on tangible proposals with a built-in accountability system. This accountability forces the legislators as candidates to make some tough choices. They would be forced to balance electoral pressures and ideological commitments with their own financial security.

Second, the appropriate ideology for the representation of posterity would remain a contested question. Any present-generation representative could be a future representative. It would be an opt-in system, so that if legislators did not want to disturb their defined benefit, they would not have to "purchase" these commodities. Doing so would be suspicious because it would essentially confess a lack of interest in the future or at least demonstrate that the individual legislator is very pessimistic about the chances that the legislator's supported policies would achieve their intended effects. This proposal does not preordain what the future interests are or what the

cannot abridge the powers of a succeeding legislature."); see also 1 WILLIAM BLACKSTONE, COMMENTARIES 90 ("Acts of parliament derogatory from the power of subsequent parliaments bind not... Because the legislature, being in truth the sovereign power, is always of equal, always of absolute authority: it acknowledges no superior upon earth, which the prior legislature must have been, if it's [sic] ordinances could bind the present parliament."). But see Eric A. Posner \& Adrian Vermeule, Legislative Entrenchment: A Reappraisal, 111 YALE L.J. 1665, 1666 (2002) ("The rule barring legislative entrenchment should be discarded; legislatures should be allowed to bind their successors, subject to any independent constitutional limits in force."). 
appropriate ideology to realize those interests is. Instead, it builds in accountability by connecting present actors with future interests.

Despite these attributes, the proposed system would also have flaws. First, it might encourage voters to reelect incumbents, creating greater numbers of career politicians, because there would be an even greater incentive to fight long policy battles to protect prior investments in certain policy choices. Second, some of the calculations necessary to realize this proposal might be unsavory. For example, how much should the death of a soldier on the battlefield cost a politician in retirement? Third, other calculations might be difficult to make because it will be difficult to value some of the policy's aims. For example, what is the value of national security?

These problems are surmountable. The development of future commodities markets such as the Iowa Electronic Market demonstrates that the outcomes of a policy alter the pensions of its supporters and opponents. ${ }^{166}$ Legislators (or more likely their staff) could trade these credits and potentially even bequeath them to their successors. The point is that the creation of this market would make the future success of policies a commodity and tie politicians' future incomes to this commodity. They would have a real incentive to care about future generations and monitor past policies so that they positively affect their own interests and, consequently, posterity.

\section{CONCLUSION}

Despite the potentially "enormous impact" of legislative policies on future generations, policymakers do not adequately consider posterity's interests when legislating. Although several environmental ethicists have proposed the idea of assigning certain legislators to represent posterity's interests, the proposal has received little serious attention from the legal academy. Although this critique does not claim to be a comprehensive evaluation of the proposal's promise and flaws, this Note makes the persistent questions regarding this proposal clearer and readier for resolution.

Whether society ultimately recognizes its obligation to future generations and institutionalizes it in the form of a posterity-oriented legislature is a question of policy and a question of ethics. It is easier to accomplish this goal, though, if the proposal is more feasible and effective. Linking legislative pensions to the performance of

166. See supra notes $160-63$ and accompanying text. 
legislative enactments while the legislator was in office would create an accountability mechanism for present-generation legislators' promises to future generations. By further developing this approach, society may develop a system that encourages legislators to better account for the impact policies have on future generations. In doing so, present generations may better realize their commitment to posterity. 